\title{
THE ANALYSIS OF THE CORRELATION BETWEEN THE LEVEL OF THE BANK FEES FOR CARDS AND THE NUMBER OF ACTIVE CARDS, CONDUCTED WITH THE HELP OF THE „PEARSON” COEFFICIENT
}

\author{
Iulia Iuga ${ }^{1}$
}

\begin{abstract}
The evolution of human society in all areas, and especially the economic field, required the banking offer to adapt to new requirements, which called for the modernization and the development of the services provided by the bank to its customers, but also becoming close to them. The goal we set with this article is to examine in terms of methodology the correlation between the number of active cards and the fees level with "PEARSON" coefficient. It is study the level of fees practiced by Raiffeisen Bank is/ is not greatly influenced (depend or doesn't depend) by the number of active cards, meaning there are other factors influencing the fees levels.
\end{abstract}

Key words: transactions, active cards, cards, Pearson coefficient.

JEL codes: G21

\section{Introduction}

The issued cards are cards that can be used to pay for a product or a service, being based on an organized system with contractual basis between holder, issuer and trader or service provider. The bank's clients use the cards both in lei and in foreign currency, at home or abroad.

In what follows I will attempt to highlight the development of the cards issues by Raiffeisen Bank in the last six years.

\section{Literature review}

In Europe, for instance, the European Commission and the Parliament have set up a new regulatory framework, the Payment System Directive, and supported the SEPA project, so as to facilitate entry and promote competition in payment card markets. Some merchants have taken advantage of this new context by launching a merchant European Payment Scheme called Payfair. This payment system is designed to offer to the merchants payment solutions at a lower cost, enabling them to choose between various options, as the services (such as the payment guarantee) are unbundled. The regulatory authorities are also monitoring closely the level of the interchange fees that are set by the payment card systems. For instance, an agreement has been reached between MasterCard and the European Commission in April 2009 to lower its interchange fee level, such that the merchants do not pay a fee that exceeds their benefit of accepting cards. The European Commission has also launched recently an enquiry against Visa about the level of the interchange fees and other system rules and practices.

Credit cards are highly complex financial instruments. Their usage reflects a large number of different characteristics and motivations (transactions, debt, consumer benefits etc.), involve a large number of prices (interest rates, teaser rates, grace periods, penalty fees, annual fees etc.) and quantity constraints (credit limits, minimum payments). The article by Ausubel (1991) was one of the first to examine in detail the significant pricing distortions inherent in the market for credit cards, and to propose possible explanations for these distortions. Humphrey et al., 1996 attempt to estimate how consumer payments break down between different payment mechanisms in different

\footnotetext{
${ }^{1}$ Universitatea “1 Decembrie 1918” Alba Iulia, N. Iorga str., no. 11-13, Alba Iulia, Iuga_iulia@yahoo.com
} 
countries. They examine a variety of types of payments including cash, checks, other paper based payments as well as electronic payments which include both credit and debit cards that are used at the point of sale (EFTPOS).

The first Visa Business debit card in USD was issued in 1996, which was a card for companies whose employees travel abroad on business interest.

A milestone for the credit card business was the launch of the Visa Business credit card in the fall of 2003, a product that practically opened the market of credit cards with a grace period.

In April 2005, the co-branded Raiffeisen Bank-Conex credit card was launched at national level and by the end of the year, 23000 Conex subscribers benefited from the advantages of this card. In the same year, in October, the bank launched the Raiffeisen Colet fidelity program, which gave the cardholders discounts in the form of collected points at the bank's partner stores. 63255 credit cards (until the year 2004, 36774 credit cards were issued) and 125000 debit cards were issued in 2005.

In 2006, Raiffeisen Bank had remarkable performances, reaching the highest number of debit cards issued by a bank in Romania in one year, 265288 VISA cards. In terms of debit cards, 65000 were issued.

Raiffeisen Bank strengthened its position on the cards market in 2007, recording significant increases in terms of issuing cards and in terms of acceptance. The credit cards held by the bank at that moment were: Standard, Gold and Vodafone. On June 12, 2007, this bank issued its $200000^{\text {th }}$ credit card. Thus, until the end of the year, the number of issued credit cards reached 245387. By making the necessary calculations, it results that the number of credit cards issued that year was 49047 and the number of debit cards was 134780 .

The credit cards issued by the end of $\mathbf{2 0 0 8}$ reached 294434 , out of which 59566 were issued only in 2008. The number of issued debit cards was 141000 .

Minor turbulences were felt in 2009, when only $\underline{78712}$ debit cards were issued. Our country and our enterprises were affected by the economic crisis, and implicitly it affected the employees from various working sectors. For this reason the employees who lost their jobs gave up their cards because they were useless. Their wages were no longer transferred on cards, they became unemployed and they were forced to give up their cards because Raiffeisen Bank didn't have an agreement with the National Agency for Employment regarding the transfer of the unemployment allowance on cards. Raiffeisen Bank issued $\underline{60000}$ credit cards in 2009.

Raiffeisen Bank and Rev Europe marked a premiere on the cards market when the VISA Raiffeisen Bank debit card was launched. This was the only pre-paid card that allowed Romanian citizens to wire money directly from their mobile phone, being at the same time the first pre-paid debit card issued by a banking institution in Romania (Ziarul Financiar, March 10, 2009).

The results for the cards issued in 2010 until March were pretty good considering the turbulences on the financial market, followed by the steep recessions. Raiffeisen Bank has a network of over 1000 ATMs and 8000 EPOS machines. $\underline{11400}$ debit cards and $\underline{6000}$ credit cards had been issued by March of this year. The overall number of cards issued by Raiffeisen Bank was 1500000 for debit cards and 360000 for credit cards.

\section{Research methodology}

The following table shows the number of cards issued in the last six years $(2005,2006$, 2007, 2008, 2009, 2010) by Raiffeisen Bank. 
Table no. 1

Number of issued cards

\begin{tabular}{|l|c|c|c|c|c|c|}
\hline \multicolumn{1}{|c|}{ Year } & $\mathbf{2 0 0 5}$ & $\mathbf{2 0 0 6}$ & $\mathbf{2 0 0 7}$ & $\mathbf{2 0 0 8}$ & $\mathbf{2 0 0 9}$ & $\begin{array}{c}\mathbf{2 0 1 0} \\
\text { (March) }\end{array}$ \\
\hline $\begin{array}{l}\text { Nype of card of } \\
\text { DEBIT cards }\end{array}$ & 125.000 & 265.288 & 134.780 & 141.000 & 78.712 & 11.400 \\
\hline $\begin{array}{l}\text { Number of } \\
\text { CREDIT cards }\end{array}$ & 63.255 & 65.000 & 49.047 & 59.566 & 60.000 & 6000 \\
\hline Total & 188.255 & 330.288 & 183.827 & 200.566 & 138.712 & 17.400 \\
\hline
\end{tabular}

Source: Raiffeisen Bank Annual Report 2005,2006,2007,2008,2009

Based on the data in the table above, I will try to show the development of the cards issues by Raiffeisen Bank in the last six years with the help of two charts, the first being below:

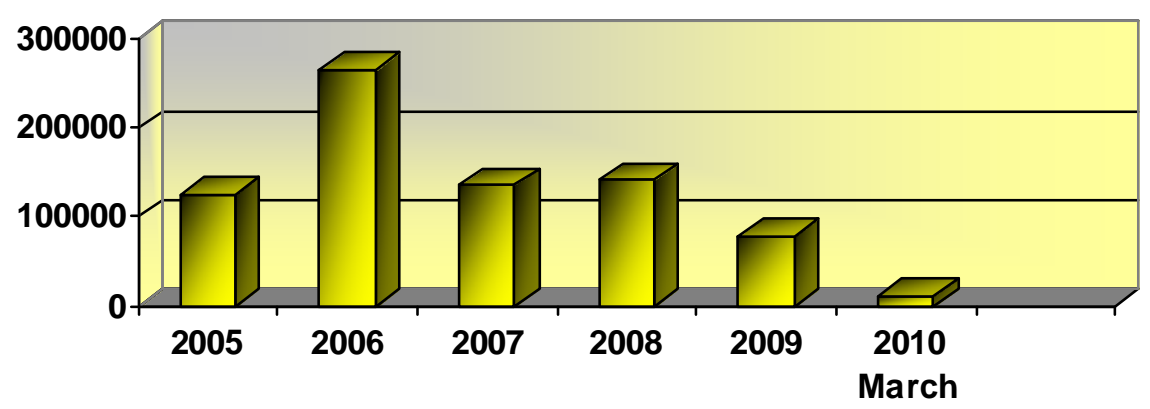

Fig. no. 1 - The development of the debit cards issued in the last six years

As mentioned previously, 2006 represents the maximum for the number of debit cards issued by Raiffeisen Bank. 130508 fewer cards were issued in 2007, meaning that this year wasn't successful in this department. A minor increase was felt in 2008, when the bank issued 6220 more cards than in 2007. The financial crisis that affected Romania was felt in the banking sector also, so in 2009 the number of issued debit cards dropped again. For the year 2010 we only have data for the first three months, but we can see a good start in terms of issued cards.

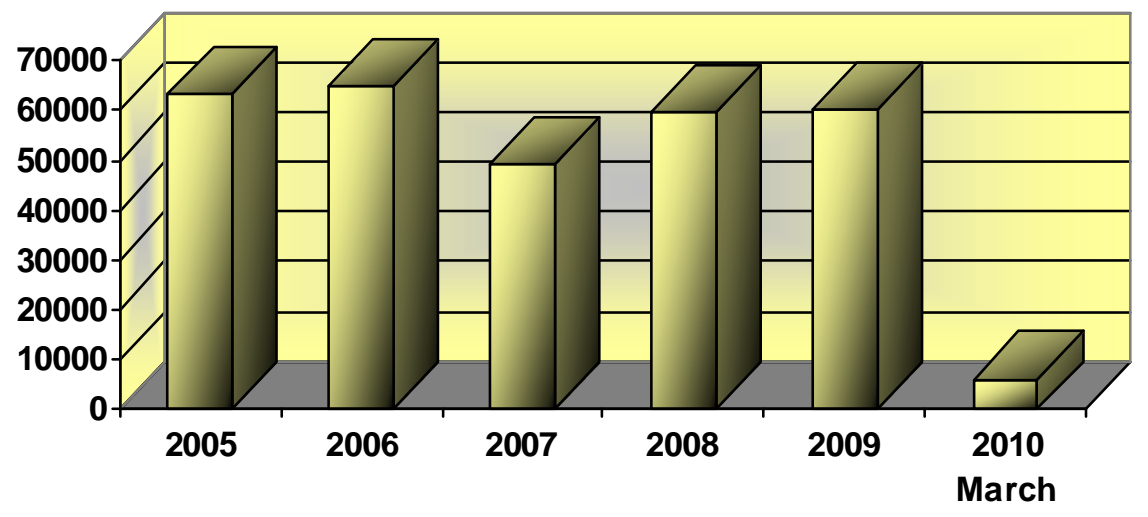

Fig. no. 2 - The development of the credit cards issued in the last six years 
In the chart above we can see an increase for the cards issued in 2006 compared to 2005, and 2007 brings a decrease of almost 15953 cards. In 2008 and 2009, the numbers of issued credit cards were very close, with only 434 more cards issued in 2009 than in 2008. As in the case of debit cards, the data for 2010 include only the first three months and they show that the number of issued cards is increasing.

\section{The evolution of transactions performed with Raiffeisen Bank cards between 2005 and 2009}

Transactions are an agreement or an understanding between the partners of an economic trading operation that includes precise clauses and conditions (Gheorghe D.Bistriceanu, 2006, p.467). They represent exchange transactions between a buyer and a seller.

In terms of the number of transactions performed with Raiffeisen cards in the last five years, they have the following values:

Table no. 2 The number of transactions performed with Raiffeisen Bank cards

\begin{tabular}{|c|c|c|c|c|c|}
\hline YEARS & 2005 & 2006 & 2007 & 2008 & 2009 \\
\hline $\begin{array}{r}\text { NUMBER OF } \\
\text { TRANSACTIONS }\end{array}$ & $\begin{array}{l}24 \\
\text { million }\end{array}$ & $\begin{array}{l}50 \\
\text { million }\end{array}$ & $\begin{array}{l}29.6 \\
\text { million }\end{array}$ & $\begin{array}{l}32.3 \\
\text { million }\end{array}$ & $\begin{array}{l}35,6 \\
\text { million }\end{array}$ \\
\hline
\end{tabular}



Fig no. 3 - The development of the number of transactions performed with Raiffeisen Bank cards

The number of transactions performed with Raiffeisen Bank cards (payment at dealers and cash withdrawals) in $\mathbf{2 0 0 5}$ exceeded 24 million, an increase of 25\% compared to 2004. The year 2006 was the economic boom in terms of the number of transactions performed with Raiffeisen Bank cards (payment at dealers and cash withdrawals). Their number doubled compared to 2005 because card holders enjoyed a grace period of 56 days with $0 \%$ interest and 51 more new units were opened, which helped at making the transactions easier.

The number of processed cash transactions exceeded 29.6 million in 2007, which was an increase compared to 2006. These transactions recorded an upward trend in $\mathbf{2 0 0 8}$ and in 2009 also, influencing in a positive manner the activity of Raiffeisen Bank.

The evolution of the value of transactions performed with Raiffeisen Bank cards between 2005 and 2009

Between 2005 and 2009 the value of the transactions performed with cards recorded the following numbers: 
Table no. 3

The value of the transactions performed with Raiffeisen cards

\begin{tabular}{|l|l|l|l|l|c|}
\hline \multicolumn{1}{|c|}{ YEARS } & $\mathbf{2 0 0 5}$ & $\mathbf{2 0 0 6}$ & $\mathbf{2 0 0 7}$ & $\mathbf{2 0 0 8}$ & $\mathbf{2 0 0 9}$ \\
\hline $\begin{array}{l}\text { TRANSACTION } \\
\text { VALUE (RON) }\end{array}$ & 6.5 billion & 8.3 billion & 11,7 billion & 13 billion & 15.2 billion \\
\hline
\end{tabular}

Based on the table above, I will highlight the development of these values with the help of the following chart:

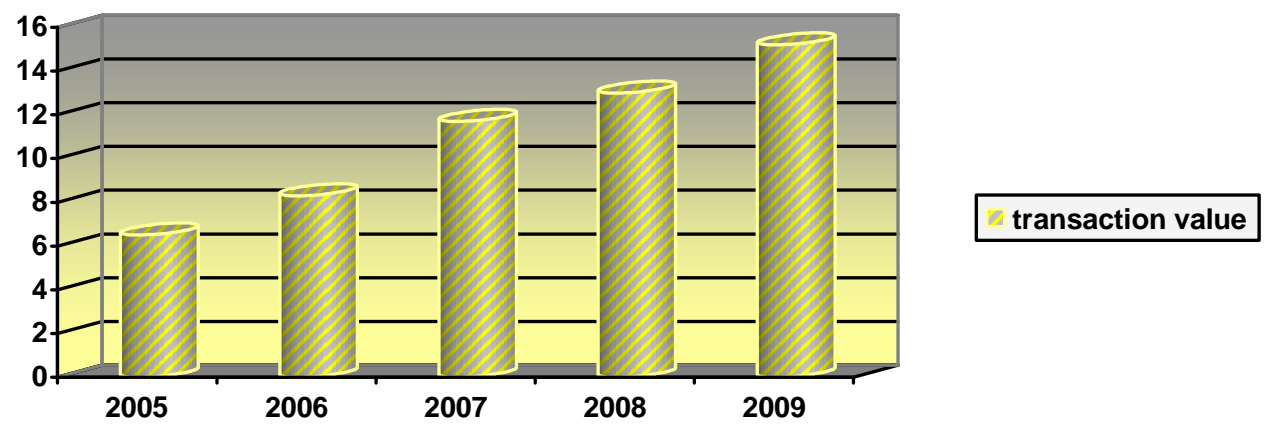

Fig. no.4 - The development of the value of transactions performed with Raiffeisen Bank cards

The value of transactions performed with Raiffeisen Bank cards in 2005 increased by 55\% compared to 2004, exceeding 6.5 billion RON. In 2006, their value recorded a growth of $33 \%$ compared to 2005 , exceeding 8.3 billion RON.

The value of the transactions increased by $31 \%$ in 2007 compared to 2006, exceeding 11.7 billion RON. The bank reconfirmed its direction towards innovation, attaching new features and services to credit cards, such as: payment by instalment, Card Protection, Purchase Protection and Price Protection. The number of transactions processed in $\mathbf{2 0 0 8}$ was continuously growing, reaching a value of approximately 13 billion RON. The year $\mathbf{2 0 0 9}$ recorded the highest value for transactions performed by cards between 2005 and 2009.

The chart shows an upward trend for the value of transactions performed with Raiffeisen Bank cards.

In 2005, both the number and the value of transactions recorded the lowest numbers for the 2005-2009 period. The year 2006 brought the highest number of transactions for the studied period, while their value was higher only by 1.8 billion RON compared to 2005 . In 2007, the number of transactions corresponds to their value, and the same situation was recorded in 2008. The same thing can't be said about 2009, by studying the charts we see that their value was a boom, while the number of the transactions was only half of their value.

Therefore, by looking at the charts we see that the number of the card transactions in 2006 corresponds to the value recorded in 2009 because they have the highest values.

The evolution of the active cards held by Raiffesen Bank between 2005 and 2009

Active cards are cards in circulation, which their owners may use for various operations.

Raiffeisen Bank started with 70000 active cards in 2001. This study will follow their evolution between 2005 and 2009.

At the end of 2005, the bank held $16 \%$ of the active cards, meaning 1128300 cards. It represents an increase compared to 2004 when the bank held 900000 active cards. At the end of 2006, $15.5 \%$ of the total active card on the market belonged to Raiffeisen Bank, meaning 1403406 
cards. The active cards portfolio reached 1689710 cards at the end of 2007, and by the end of 2008 it exceeded 1790000 active cards. The year $\mathbf{2 0 0 9}$ ended with 1954200 active cards.



Fig. no. 5 - The evolution of active cards between 2005 and 2009

Source: Raiffeisen Bank Annual Report 2005,2006,2007,2008,2009

The active cards of the bank had a positive trend. This evolution is visible in the chart above, each year recording a growth of active cards. From 2005 to 2006, their number increased by 275106, from 2006 to 2007, it increased by 286304, from 2007 to 2008, by 100290, and from 2008 to 2009 , it increased by 164200 .

The positive evolution of the active cards number gives Raiffeisen Bank a good image. We realize the bank wasn't extremely affected by the economic recession that our country is facing and it is carrying on its activity like under normal circumstances.

The analysis of the correlation between the level of the bank fees for cards and the number of active cards, conducted with the help of the ,PEARSON" coefficient

The correlation coefficient PEARSON is a dimensionless index included in the range [-1 and 1] and reflects the extent of the linear relationship between two sets of data.

Table no.5

The fees level for cards and active cards at Raiffeisen Bank

\begin{tabular}{|l|l|l|l|l|l|}
\hline YEARS & $\mathbf{2 0 0 5}$ & $\mathbf{2 0 0 6}$ & $\mathbf{2 0 0 7}$ & $\mathbf{2 0 0 8}$ & $\mathbf{2 0 0 9}$ \\
\hline $\begin{array}{l}\text { NUMBER OF ACTIVE } \\
\text { CARDS (X) }\end{array}$ & 1.128 .300 & 1.403 .406 & 1.689 .710 & 1.790 .000 & 1.954 .200 \\
\hline FEES LEVEL(Y) & $\begin{array}{l}1.06 \% \\
(0,672)\end{array}$ & $\begin{array}{l}1,36 \% \\
(0,735)\end{array}$ & $\begin{array}{l}1.65 \% \\
(0,8605)\end{array}$ & $\begin{array}{l}1,45 \% \\
(0,6235)\end{array}$ & $\begin{array}{l}1,19 \% \\
(0,6055)\end{array}$ \\
\hline
\end{tabular}

Source: Raiffeisen Bank Annual Report 2005,2006,2007,2008, 2009

The calculus formula for the PEARSON coefficient is:

$$
R_{01}=\frac{\operatorname{cov}(x, y)}{\sigma x * \sigma y}=\frac{M(x y)-M(x) M(y)}{\sigma x * \sigma y} \in[-1,1]
$$

- If the result of the PEARSON coefficient is negative $\rightarrow$ high correlation where $\mathrm{x}$ increases and y drops;

- If the result of the PEARSON coefficient is positive $\rightarrow$ direct correlation where $\mathrm{x}$ increases and y increases; 
- If the result of the PEARSON coefficient $=0 \rightarrow$ weak correlation.

In our case: $\mathrm{X}$ - the number of active cards is the influence factor, and $\mathrm{Y}$ - the fees level is the influenced factor. Initially, we may say that the fees level is influenced by the number of active cards.

$$
\begin{aligned}
& M(x * y)=(x 1 * y 1+x 2 * y 2+x 3 * y 3+x 4 * y 4+x 5 * y 5) / n \\
& \mathrm{M}(\mathrm{x} * \mathrm{y})=(1128300 * 0,672+1403406 * 0,735+1689710 * 0,8605+1790000 * 0,6235+ \\
& 1954200 * 0,6055) / 5 \rightarrow \mathbf{M}\left(\mathbf{x}^{*} \mathbf{y}\right)=\mathbf{1 1 0 8 6 0 9 , 9 1 3} \\
& M(x) * M(y)=\bar{X} * \bar{y} \text {, where } \bar{X} \text { represents the mean of } x \text { and } \bar{y} \text { - the mean of } y \text {; } \\
& \bar{X}=(1128300+1403406+1689710+1790000+1954200) / 5=1593123,2 \\
& \bar{y}=(0,672+0,735+0,8605+0,6235+0,60550) / 5=0,6993 \\
& \mathrm{M}(\mathrm{x}) * \mathbf{M}(\mathrm{y})=1593123,2 * 0,6993 \rightarrow \mathbf{M}(\mathbf{x}) * \mathbf{M}(\mathbf{y})=\mathbf{1 1 1 4 0 7 1 , 0 5 3 7 6} \\
& \sigma x=[(x 1-\bar{X})+(x 2-\bar{X})+(x 3-\bar{X})+(x 4-\bar{X})+(x 5-\bar{X})] / 5 \\
& \boldsymbol{\sigma} \boldsymbol{x}=[(1128300-1593123,2)+(1403406-1593123,2)+(1689710-1593123,2)+ \\
& (1790000-1593123,2)+(1954200-1593123,2)] / 5 \\
& \rightarrow \sigma x=-654540,4+654540,4=0 \\
& \sigma y=(y 1-\bar{y})+(y 2-\bar{y})+(y 3-\bar{y})+(y 4-\bar{y})+(y 5-\bar{y}) / 5 \\
& \boldsymbol{\sigma y}=[(0,672-0,6993)+(0,735-0,6993)+(0,8605-0,6993)+(0,6235-0,6993)+ \\
& (0,6055-0,6993)] / 5 \rightarrow \sigma y=0
\end{aligned}
$$$$
\text { PEARSON Coefficient }=(1108609,913-1114071,05376) / 0=0
$$

The result of the "PEARSON" coefficient is 0 , which means there is a weak correlation between the number of active cards and the fees level. Therefore, the level of fees practiced by Raiffeisen Bank is not greatly influenced (doesn't depend) by the number of active cards, meaning there are other factors influencing the fees levels. Among these factors are included: the type of the issued cards, the performed operations and the number of issued cards.

\section{Conclusions}

Thus, cards of different types have began to be used increasingly more in countries with developed economies, shortly becoming one of the most widespread and used banking services. Currently, in Romania, the card is one of the most spread methods of payment and ways to obtain a credit. The plastic card takes many forms and is the "key" to any transaction of electronic transfer at the place of the purchase. Therefore, the level of fees practiced by Raiffeisen Bank doesn't depend by the number of active cards, meaning there are other factors influencing the fees levels. Among these factors are included:

1. the type of the issued cards,

2. the performed operations and

3 . the number of issued cards.

For the future development of cards, the accomplishment of the following ideas is aimed: Entering production for a new payment procedure in the euro area TARGET SECURITIES by 2013. A growth of the card transactions is considered for the following years. 


\section{References:}

1. Ausubel, L.M., 1991. The failure of competition in the credit card market.The American Economic Review 81 (1), p. 50-81

2. Bistriceanu D. G., 2006. Mică Enciclopedie de Finanțe, Universitară Publishing House, Bucureşti

3. Bourreau M., Marianne Verdier, 2010. Private cards and the bypass of payment systems by merchants, Journal of Banking \& Finance NO. 34, p.1799

4. Breaz, N., 2009. Statistică - Note de curs şi seminarii, Universitatea "1 Decembrie Alba Iulia" Publishing House

5. Briciu, S., Iuga, I, Socol A., 2009. An Analysis of the SEPA Cards Framework (Single Euro Payments Area) Adoption in Romania, Analele Universității din Oradea, seria Ştiințe Economice, Tom XVIII"

6. Demirgüç-Kunt A., Harry Huizinga, 2009. The Impact on Risk and Returns, Policy Research Working Paper 4837, Bank Activity and Funding Strategies, The World Bank Development Research Group, Finance and Private Sector Team

7. Famy G., 2007. Managing market risk with conditioning information, Journal of Asset Management 7, 412 - 418

8. Humphrey, D.B., Pulley, L.B., Vesala, J.M., 1996. Cash, paper, and electronic payments: a cross-country analysis. Journal of Money, Credit, and Banking, Part 228 (4), 914-939

9. Iuga, I., Roşca, T., 2005. Monedă şi credit, Risoprint Publishing House, Cluj Napoca

10. Barry, S., Massoud, N., Saunders, A., Carbo-Valverde, S., Rodriguez-Fernandez, F., 2008. The economics of credit cards, debit cards and ATMs: A survey and some new evidence, Journal of Banking \& Finance 32 1468-1483

11. Annual Report, 2005,2006,2007,2008, 2009, Raiffeisen Bank;

12. www.ECB.ro

13. www.BNR.ro

14. www.Raiffeisen.ro

15. www.analizafinanciară.ro

16. www.ghişeulbancar.ro 